Kajian Jurnalisme

ISSN 2549-0559 (cetak) ISSN 2549-1946 (online)

Volume 01 Nomor 02 Tahun 2018

\title{
Wacana Pernikahan Sesama Jenis Di Tv One
}

\author{
Ardiansyah Megah Putra dan Siti Karlinah, \\ Program Studi Jurnalistik, Fakultas Ilmu Komunikasi, Universitas Padjadjaran \\ e-mail: ardinosaires@gmail.com
}

\begin{abstract}
This study wanted to know how TV One created same-sex marriage discourse in the "Debat" program, "Nikah Sesama Jenis, Manusiawi atau Eksistensi?" episode, 6th of July 2015 through text dimension, discourse practice dimension, and sociocultural practice dimension. The result showed that in the level of text, the ideology from the cons to refuse the same-sex marriage discourse in Indonesia is very dominating the program, because they got more chance to speak from the host than the pros. At the level of discourse practice concluded that policy from the redaction team of TV One which is counter towards same-sex marriage discourse affecting the production and consumption process of text. At the level of sociocultural practice revealed that generally, Indonesian society still hardly against same-sex marriage discourse to be approved and to be legalized in the country.

Research suggests that TV One capable to report issue about LGBT people into a discussion program with the principle of impartiality, either in the context of giving times or presenting the interviewees, in order to produce a lot of smart audiences and be more opened to the diversity in the society.
\end{abstract}

Keywords: lgbt, lesbian, gay, bisexual, transgender, same-sex marriage discourse, critical discourse analysis, norman fairclough, tvone.

\begin{abstract}
Abstrak
Penelitian ini ingin mengetahui bagaimana TV One menciptakan wacana pernikahan sesama jenis dalam program "Debat", "Nikah Sesama Jenis, Manusiawi atau Eksistensi?" episode, 6 Juli 2015. Penelitian dilakukan dengan metode Analisis Wacana Kritis model Norman Fairclough, dengan fokus analisis pada dimensi teks, praktik wacana, dan praktik sosiokultural. Hasil penelitian menunjukkan bahwa pada tingkat teks, ideologi dari pihak yang kontra menolak wacana pernikahan sesama jenis di Indonesia sangat mendominasi program tersebut, karena mereka mendapat lebih banyak kesempatan untuk berbicara dari tuan rumah daripada yang profesional. Pada tingkat praktik wacana disimpulkan bahwa kebijakan dari tim redaksi TV One yang berlawanan dengan wacana pernikahan sesama jenis mempengaruhi proses produksi dan konsumsi teks. Pada tingkat praktik sosiokultural terungkap bahwa secara umum, masyarakat Indonesia masih sulit menentang wacana pernikahan sesama jenis untuk disetujui dan dilegalkan di negara tersebut.
\end{abstract}

Kata Kunci : LGBT, analisis wacana kritis, TV_One 
Volume 01 Nomor 02 Tahun 2018

\section{Pendahuluan}

Tepat pada 26 Juni 2015, seluruh kaum LGBT di Amerika Serikat merayakan putusan pernikahan sesama jenis yang dilegalkan oleh Mahkamah Agung Amerika Serikat terhadap seluruh negara bagiannya. Keputusan ini cukup bersejarah, karena Amerika Serikat merupakan negara barat terakhir selain Australia yang mengesahkan pernikahan sesama jenis dan berlaku penuh di seluruh negara bagiannya.

Sebagai salah satu negara adidaya, keputusan yang diambil oleh Amerika ini cukup menuai reaksi, khususnya terhadap masyarakat Indonesia. Hal ini terlihat oleh sejumlah publik figur yang mengutarakan pendapatnya dari sisi pro dan kontra. Misalnya saja seperti penyanyi ternama Anggun C Sasmi dan Sherina Munaf yang menyatakan keterbukaannya akan putusan ini melalui cuitan di Twitter. Bahkan, melalui postingan di Instagram, pelawak Aming secara terang-terangan menghadiri parade gay yang berlangsung di New York, Amerika Serikat pada 28 Juni 2015 (dua hari setelah dilegalkannya pernikahan sesama jenis).

Berusaha menanggapi isu yang sedang berkembang pada saat itu, Menteri Agama Lukman Saifuddin selaku bagian dari pemerintahan turut mengungkapkan tanggapannya di Twitter. Ia dengan tegas menyatakan bahwa negara menolak adanya wacana pernikahan sesama jenis di Indonesia.

Di saat isu ini sedang ramai diperbincangkan publik, TV One memiliki keberanian untuk mengemas secara khusus wacana pernikahan sesama jenis di Indonesia ke dalam bentuk dialog/wawancara (views) secara live pada program Debat. Program Debat sendiri adalah acara diskusi yang menampilkan dialog terbuka antara dua kubu berseberangan yang memaparkan analisa disertai argumen-argumen dukungan atau penentangan (pro-kontra) juga kesimpulan mengenai sebuah isu yang hangat dibicarakan masyarakat dengan dikaji oleh beberapa tokoh undangan sebagai pemerhati topik yang diperdebatkan.

Keberanian ini diperjelas oleh M Heychael selaku Direktur Remotivi (lembaga penelitian di bidang media) yang mengungkapkan bahwa tindakan TV One ini menjadikannya sebagai media penyiaran pertama di Indonesia yang menayangkan program dialog secara langsung (live) berdiskusi tentang isu sensitif, tepatnya mengenai kelompok LGBT. Pernyataan Heychael ini juga kemudian ditambah oleh Nur Khoiron sebagai salah satu Komisioner Komnas HAM yang bertanggung jawab atas isu-isu LGBT. Ia mengatakan bahwa kelompok LGBT berada di tingkatan yang paling rendah dari sekian banyak kelompok marjinal lainnya yang ada di Indonesia.

Di sisi lain, keberanian $T V$ One dalam mengupas isu yang terbilang cukup sensitif ini dilakukan di negara Indonesia, negara yang orientasinya masih sangat kental akan budaya dan agama. Sesuai dengan apa yang disebutkan oleh Hatib Abdul Kadir Olong dalam bukunya yang berjudul Tangan Kuasa Dalam Kelamin bahwa kalangan agamawan di Indonesia memandang kaum homoseks identik dengan sesuatu yang "hitam", karena berani melawan rezim moral yang dibangun oleh agama serta konstruksi dominan sosial masyarakat (2007:110). Oleh karena itu, keputusan TV One dalam menaikkan isu ini pada level media yang kemudian menjadi perbincangan di ruang publik menjadi suatu kelebihan tersendiri dibandingkan dengan media lainnya. 
Episode yang berjudul "Nikah Sesama Jenis, Manusiawi atau Eksistensi?" tayang pada 6 Juli 2015 dengan durasi 55 menit (dengan iklan). Acara ini dibawakan oleh Dwi Anggia selaku pembawa acara (host). Dwi mengundang sebanyak 4 narasumber yang dibagi menjadi 2 kubu, pro dan kontra. Pihak pro diwakili oleh Dede Oetomo (Pendiri Gaya Nusantarapelopor pergerakan kaum gay di Indonesia), Yuli Rustinawati (Aktivis Arus Pelangiorganisasi LGBT), dan Jeremy Teti (Selebriti), sedangkan pihak kontra direpresentasikan oleh Neng Zubaidah (Anggota Komisi I Hukum Majelis Ulama Indonesia), Sodik Mudjahid (Wakil Ketua Komisi VIII DPR RI-komisi yang bertanggung jawab atas agama, sosial, dan pemberdayaan perempuan), dan Musni Umar (Sosiolog).

Tayangan ini kemudian dibuka dengan beberapa patah kata dari Jeremy Teti sebagai bagian dari kubu pro. Ia menjelaskan posisinya bahwa ia mendukung wacana pernikahan sesama jenis di Indonesia apabila masyarakat dan negara sendiri sudah siap menerimanya. Setelah Jeremy berbicara, program dibuka secara resmi oleh Dwi Anggia selaku host. Sehabis Dwi juga memberikan beberapa kata pembuka, diskusi antara kubu pro dan kontra pun dimulai.

Secara garis besar, intisari dari tayangan ini adalah bahwa kubu kontra menolak wacana pernikahan sesama jenis di Indonesia, karena landasan hukum seperti UUD 1945 dan Pancasila, serta norma agama dan budaya di Indonesia tidak ada yang bisa mengakui wacana ini. Di sisi lain, kubu pro juga tetap berpegang teguh dengan argumen bahwa hukum dan budaya di Indonesia bisa berubah, sehingga hal yang bisa dilakukan adalah dengan cara melakukan amendemen terhadap undang-undang jika masyarakat dan negara sudah siap melakukannya.

Di penghujung acara, tayangan ini mulai menunjukkan tanda bahwa TV One tidak menerapkan prinsip cover both side. Asumsi ini mulai muncul di akhir segmen ke-4 dan berlanjut hingga segmen terakhir di mana Dwi Anggia selaku host yang seharusnya bertindak sebagai penyeimbang atau pihak yang netral lebih banyak memberikan kesempatan kepada kubu yang kontra untuk terus berbicara dibandingkan dengan kubu yang pro.

Ketika kubu pro akan melakukan sanggahan/interupsi terhadap kubu kontra, Dwi cenderung tidak memberikan kesempatan. Terkadang ia memotong atau membiarkan kubu pro yang sedang berargumen dipotong oleh kubu kontra. Oleh karena itu, pada bagian ini telah muncul suatu motif bahwa redaksi TV One yang direpresentasikan oleh Dwi Anggia sebagai host menunjukkan adanya sikap keberpihakan terhadap kubu kontra.

Selama tayangan berlangsung, kubu kontra juga terlihat melakukan upaya untuk menyudutkan kedua narasumber kubu pro yang memang merupakan bagian dari kelompok LGBT, di mana Dede Oetomo dari Gaya Nusantara dan Yuli Rustinawati dari Arus Pelangi. Upaya penyudutan ini dilihat melalui kesempatan bagi kubu pro untuk berbicara yang cenderung diberikan tidak proporsional atau tidak berimbang oleh Dwi Anggia selaku sang pembawa acara, sehingga sulit bagi mereka untuk melawan argumen ketiga lawan debatnya yang sebagian besar melawan dengan perspektif agama.

Oleh karena itu, perspektif yang sesuai dalam meneliti wacana ini adalah dengan menggunakan perspektif Hak Asasi Manusia (HAM) di mana setiap orang, termasuk kaum LGBT, memiliki kedudukan yang sama di hadapan hukum dan negara, tanpa memandang 
orientasi seksual, identitas gender, dan perilaku seksualnya. Kelompok heteroseksual dan homoseksual juga seharusnya dapat dipahami sebagai sesuatu yang setara. Akan tetapi pada realitasnya, kehadiran homoseksual lebih dianggap sebagai sebuah penyimpangan sosial ketika kelompok heteroseksual dalam realitasnya juga melakukan penyimpangan sosial, layaknya perselingkuhan dan kumpul kebo.

Berdasarkan pertimbangan itu pula, wacana dalam program "Debat" TV One dengan judul "Nikah Sesama Jenis, Manusiawi atau Eksistensi?" yang tayang pada 6 Juli 2015 menarik untuk diteliti dengan harapan bahwa penelitian ini dapat menjawab asumsi mengenai sejauh mana media menempatkan diri dalam memberitakan isu yang kontroversial. Apakah telah terjadi penggiringan wacana dan mediasi ideologi oleh $T V$ One yang direpresentasikan oleh host? Atau apakah memang benar ada usaha menyudutkan kelompok LGBT dari $T V$ One melalui kubu kontra?

Dalam melakukan penelitian ini, pendekatan yang digunakan adalah Analisis Wacana Kritis (AWK) model Norman Fairclough untuk memahami wacana pernikahan sesama jenis di Indonesia yang muncul dalam tayangan ini. AWK sendiri menurut Fairclough dan Wodak (dalam Eriyanto, 2012:7) digunakan untuk melihat wacana-pemakaian bahasa dalam tuturan dan tulisan-sebagai bentuk dari praktik sosial. AWK melihat bahasa sebagai faktor penting, yakni bagaimana bahasa digunakan untuk melihat ketimpangan kekuasaan dalam masyarakat terjadi. Menurut mereka, AWK menyelidiki bagaimana melalui bahasa, kelompok sosial yang ada saling bertarung dan mengajukan versinya masing-masing (dalam Eriyanto, 2012:6).

Alasan lainnya adalah karena pendekatan AWK berlandaskan paradigma kritis yang memiliki pandangan tertentu tentang bagaimana media dan produk di media massa harus dipahami dalam keseluruhan proses produksi dan struktur sosial. Selain itu, paradigma kritis yang tumbuh di masa pemerintahan Hitler di Jerman ini juga memang melihat media bukan sebagai entitas yang netral di mana ia bisa dikuasai oleh kelompok dominan (Eriyanto, 2011:23). Dengan kata lain, menjadi sesuatu yang wajar apabila dalam realitasnya paradigma ini melihat tidak ada media yang mampu bersikap "independen" atau istilah lainnya "tidak berpihak".

Oleh karena itu, dalam melakukan penelitian ini, peneliti tidak hanya melakukan analisis terhadap setiap teks yang muncul dalam tayangan, tetapi juga praktik diskursus wacana dan praktik dalam konteks sosiokultur masyarakat yang direpresentasikan dalam pertanyaan dan pernyataan host, serta argumen (pernyataan maupun sanggahan) sejumlah narasumber dari sisi pro dan kontra demi membedah wacana yang terkandung di dalamnya, yakni wacana pernikahan sesama jenis di Indonesia.

\section{Pembahasan}

Level Teks

Dalam analisis wacana kritis model Norman Fairclough, bahasa atau teks tidak hanya dipandang sebagai dengan cara objek itu digambarkan, melainkan teks memiliki hubungan yang erat di antara objek-objek yang disajikan. Menurut gagasan Fairclough, setiap teks pada 
dasarnya bisa diuraikan dan dianalisis menggunakan tiga unsur, yakni representasi, relasi, dan identitas (dalam Eriyanto, 2008:289).

Fairclough mengartikan representasi sebagai cara bagaimana seseorang, kelompok, atau gagasan ditampilkan dalam bentuk anak kalimat, kombinasi, atau gabungan anak kalimat, serta rangkaian antaranak kalimat. Mengacu pada definisi tersebut, analisis representasi pada penelitian ini dilakukan dengan melihat dua komponen, yaitu tata bahasa dan kosa kata. Kedua aspek tersebut dapat dilihat melalui anak kalimat, kombinasi anak kalimat, dan rangkaian anak kalimat yang terdapat di dalamnya (Eriyanto, 2012:290).

Representasi dalam anak kalimat sendiri dilakukan dengan cara mengetahui bentuk kosa kata atau tata bahasa yang digunakan dalam setiap anak kalimat oleh para pemakai bahasa untuk merepresentasikan sesuatu.

Pada segmen pertama, tayangan dibuka dengan footage yang menceritakan putusan mengenai legalisasi pernikahan sesama jenis yang sedang menjadi kontroversi, khususnya dalam konteks negara Indonesia. Pada bagian ini, redaksi TV One menyatakan bahwa isu ini cukup mendapatkan dukungan dari beberapa publik figur Indonesia dengan dalih hak asasi manusia. Namun Menteri Agama dikatakan menolak dan menegaskan bahwa pernikahan sejenis tak akan pernah diakui di tanah air. Di akhir tayangannya, sang penulis naskah mempertanyakan apakah pernikahan sesama jenis tetap dapat dilegalkan di Indonesia dengan dalil hak asasi manusia dengan melihat keberadaan kaum LGBT yang benar-benar ada di tanah air

Setelah itu, Neng Zubaidah mengeluarkan sejumlah pernyataan dalam konteks menolak wacana pernikahan sesama jenis di Indonesia dengan mengatasnamakan organisasi MUI yang ia jalankan, seperti menggunakan Undang-undang Nomor 1 Tahun 1974, Pasal 28I ayat 2, dan sebanyak 76 ayat tentang "larangan" mengenai homoseksual. Secara tidak langsung telah terjadi bias terhadap agama Islam oleh Neng. Ia juga menimbulkan tanda-tanda kebencian terhadap kelompok LGBT dengan penggunaan diksi "larangan" yang memiliki makna halangan, hambatan, inhibisi, pembatasan, prohibisi, restriksi $(K B B I)$ mengenai perilaku homoseksual oleh kelompok LGBT.

Dede kemudian menyanggah argumen Neng dengan berusaha menjelaskan bahwa agama di Indonesia tidak hanya Islam saja. Bahkan Islam saja ia katakan memiliki berbagai macam aliran. Menurut Dede, hal ini bukan masalah sedikit atau banyaknya jumlah pengikut suatu aliran, tetapi lebih kepada masalah "konstelasi" dan "persaingan".

"Konstelasi" sendiri memiliki makna keadaan atau tatanan (KBBI), sedangkan "persaingan" merujuk pada arti usaha memperlihatkan keunggulan masing-masing yang dilakukan oleh perseorangan (perusahaan, negara) pada bidang perdagangan, produksi, persenjataan, dan sebagainya $(K B B I)$, sehingga apa yang dimaksud oleh Dede adalah dalam beberapa waktu ke depan, Islam dengan sendirinya akan mengakui keberadaan LGBT dan menyetujui wacana pernikahan sesama jenis, tergantung dengan aliran Islam yang berkembang pada masa itu.

Neng semakin memperlihatkan sikap ketidaksukaannya terhadap kaum LGBT saat ia menyatakan bahwa MUI telah membuat suatu fatwa yang khusus melarang keberadaan LGBT. "Fatwa" sendiri memiliki makna yang berarti jawab (keputusan, pendapat) yang 
diberikan oleh mufti tentang suatu masalah $(K B B I)$, sehingga secara otomatis LGBT dipandang sebagai suatu masalah yang perlu diatasi oleh MUI.

Dede pun membalas tanggapan Neng dengan argumen bahwa "mayoritas" tidak boleh menguasai "minoritas". Penggunaan diksi "mayoritas" oleh Dede memiliki makna jumlah orang terbanyak yang memperlihatkan ciri tertentu menurut suatu patokan dibandingkan dengan jumlah yang lain yang tidak memperlihatkan ciri itu $(K B B I)$, sedangkan "minoritas" adalah golongan sosial yang jumlah warganya jauh lebih kecil jika dibandingkan dengan golongan lain dalam suatu masyarakat dan karena itu didiskriminasikan oleh golongan lain itu $(K B B I)$. Dengan tambahan kata "menguasai" yang memilkiki arti berkuasa atas sesuatu $(K B B I)$, Dede sejatinya secara halus memperingatkan kepada Neng sebegai bagian dari MUI untuk tidak boleh menjadi seseorang yang berkuasa sepenuhnya dalam mengatur kehidupan kaum LGBT.

Selanjutnya, Sodik Mudjahid selaku perwakilan dari DPR RI juga merasa apabila kelompok LGBT memaksa untuk mengakui wacana pernikahan sejenis, maka negara akan "melanggar" norma adat, budaya, agama, sila pertama Pancasila, serta pasal 29 Undangundang Dasar 1945 ayat 1 dan 2. Pada diksi "melanggar", dapat dimaknai bahwa kelompok LGBT akan menyalahi atau melawan (KBBI) segala norma, hukum, dan peraturan perundang-undangan di Indonesia dalam rangka melegalkan pernikahan sesama jenis di tanah air. Penjelasan ini terlihat cukup menyudutkan bagi pihak yang pro LGBT dan pernikahan sesama jenis, karena mereka terlihat tidak diberi ruang gerak untuk leluasa memperjuangkan hak yang mereka cita-citakan. Fakta ini juga semakin memperkuat asumsi bahwa kelompok LGBT adalah kelompok yang sangat termarjinalkan di tanah air.

Dede Oetomo selaku pelopor pergerakan kaum gay di Indonesia setuju bahwa untuk saat ini pernikahan sesama jenis tidak bisa dilakukan karena undang-undang di Indonesia sendiri belum bisa mengatur. Akan tetapi, ia melihat bahwa hukum akan selalu "berubah". Kata "berubah" sendiri mengacu pada makna menjadi lain (berbeda) dari semula $(K B B I)$. Kata ini secara tidak langsung juga mengacu pada kata "amendemen" yang memiliki arti, usul perubahan undang-undang yang dibicarakan di Dewan Perwakilan Rakyat atau penambahan pada bagian yang sudah ada (KBBI).

Dalam menanggapi ini, Sodik mengatakan bahwa norma Pancasila yang mayoritas berdasarkan sumber-sumber agama, maka "susah" untuk berubah selama pemeluknya masih memegang agama itu sendiri. Penggunaan kata "susah" dapat bermakna sukar atau tidak mudah $(K B B I)$. Sodik ingin menekankan bahwa tidak mudah mengubah hukum di Indonesia yang bersumber dari norma-norma yang telah berlaku di masyarakat, terlebih lagi apabila itu menyangkut landasan hukum seperti Pancasila dan UUD 1945. Apabila kelompok LGBT ingin tetap memperjuangkan hak-haknya, maka Sodik menyatakan akan terjadi sebuah "perang" karena landasan hukum di Indonesia harus diubah demi dapat menerima kehadiran mereka.

Penggunaan kata "perang" dalam argumen Sodik ini memiliki arti yang cukup kuat, karena dapat bermakna sebagai suatu cara untuk mengungkapkan permusuhan. Sodik sebagai wakil rakyat telah berani merepresentasikan dirinya sebagai bagian dari pemerintahan sekaligus cerminan masyarakat Indonesia yang menolak keras akan keberadaan LGBT dan 
wacana pernikahan sejenis untuk dapat diakui di Indonesia. Dengan kata lain, Sodik memberikan pemahaman kepada masyarakat bahwa tidak masalah apabila melakukan melakukan permusuhan terhadap kelompok LGBT di Indonesia.

Untuk pembahasan mengenai representasi dalam kombinasi anak kalimat sendiri dilakukan dengan cara mengetahui bentuk koherensi yang menghubungkan antara satu anak kalimat dengan anak kalimat yang lain.

Dalam membuka tayangan secara resmi dan menjelaskan alasan pemilihan topik, Dwi Anggia sebagai host juga menggunakan pilihan kata dalam konteks mempertinggi dengan kalimat "Mengapa ini menjadi tema kami? Karena pemirsa, legalisasi pernikahan sejenis di Amerika mulai menuai reaksi di Indonesia. Apa reaksinya? Sejumlah publik figur sudah secara terang-terangan memberikan dukungan terhadap lesbian, gay, transgender, dan biseksual".

Dengan kata "karena", Dwi menekankan bahwa tak hanya keberadaan LGBT saja yang menjadi faktor pendukung diangkatnya wacana pernikahan sesama jenis ke dalam tayangan ini, namun juga faktor munculnya berbagai reaksi akan wacana ini, khususnya beberapa publik figur Indonesia yang bersikap terbuka akan perihal isu yang menyangkut kaum LGBT ini, seperti Anggun C Sasmi, Sherina Munaf, dan Aming.

Selain dalam konteks mempertinggi, Dwi juga menggunakan perpanjangan kontras dalam kalimat "Namun, di sisi lain pemirsa, LGBT keberadaannya ditolak oleh masyarakat kita. Tapi tidak bisa dipungkiri dan tidak bisa dinafikan, sebagian masyarakat kita juga mulai permisif dan menerima, bahkan menikmati keberadaan mereka. Terbukti dengan adanya profil LGBT di beberapa program hiburan di media massa."

Ia menggunakan kata "namun" untuk memperlihatkan kekontrasan terhadap pernyataan yang ia utarakan sebelumnya, di mana di saat wacana pernikahan sesama jenis didukung oleh beberapa orang ternama di Indonesia, masyarakat di tanah air juga menyatakan penolakan akan keberadaan kelompok LGBT. Akan tetapi, Dwi kembali mengutarakan kekontrasan dengan memilih kata "tapi" untuk menyatakan bahwa sebagian masyarakat Indonesia juga ada yang menerima kehadiran kelompok LGBT.

Pada situasi di atas, Dwi ingin menunjukkan kepada publik bahwa posisi kaum LGBT di Indonesia yang umumnya selalu berada dalam situasi penolakan oleh masyarakat, ternyata menghadapi sebuah dinamika. Dinamika atau perubahan ini ditandai dengan mulai terbukanya masyarakat yang dipengaruhi oleh sejumlah program di media massa yang bermuatan LGBT. Bentuk keterbukaan masyarakat ini ditunjukkan oleh Dwi dengan penggunaan kata "dan" dalam konteks perpanjangan tambahan, serta kata "bahkan" dalam konteks elaborasi.

Berikutnya representasi dalam rangkaian antarkalimat. Aspek ini berhubungan dengan bagaimana kedua kalimat atau lebih disusun dan dirangkai. Salah satu aspek penting adalah apakah partisipan dianggap mandiri ataukah ditampilkan memberikan reaksi dalam teks berita (Eriyanto, 2012:296). Dikaitkan dengan tayangan Debat episode "Nikah Sesama Jenis, Manusiawi atau Eksistensi?", peneliti melihat bagaimana host dan masing-masing narasumber merangkai kata-kata yang direpresentasikan melalui pertanyaan dan pernyataan yang cenderung menonjol. 
Setelah mencermati perdebatan dari para narasumber berdasarkan representasi dalam rangkaian antarkalimat, muncul beberapa hal yang dianggap menghambat jika wacana pernikahan sejenis akan diakui di Indonesia, antara lain; (1) pernikahan adalah sebuah ikatan lahir batin yang hanya bisa dilakukan oleh pasangan lawan jenis, (2) sejumlah perangkat hukum di Indonesia yang melarang wacana ini untuk direalisasikan, serta (3) kekhawatiran akan terulangnya peristiwa serupa pada zaman Nabi Luth di mana Tuhan mengazab kaum homoseksual yang hidup pada saat itu dengan bencana besar.

Di satu sisi, kubu pro sejatinya sepakat dengan hegemoni yang dilancarkan oleh kubu kontra bahwa wacana pernikahan sesama jenis dalam konteks negara Indonesia tidak bisa dilakukan, setidaknya untuk saat ini. Pernyataan yang diungkapkan oleh kubu pro ini kemudian berkaitan dengan proses pembentukan realitas di mana Stuart Hall (dalam Eriyanto, 2012:29-31) menyatakan bahwa realitas dapat ditandakan secara berbeda pada peristiwa yang sama. Makna yang berbeda dapat dilekatkan dengan peristiwa yang sama. Hal ini berkonklusi pada pernyataan bahwa hanya satu makna yang akhirnya diterima di saat pemaknaan atas suatu realitas bisa memungkinkan banyak perbedaan penafsiran.

Asumsi dari Hall ini kemudian terbukti, karena setelah menyatakan bahwa wacana pernikahan sesama jenis tidak bisa dilakukan untuk saat ini, kubu pro menambahkan penjelasannya bahwa tidak dapat dipungkiri apabila beberapa puluh tahun ke depan wacana pernikahan sejenis akan diakui jika negara melakukan perubahan hukum atau amendemen untuk memberi ruang kepada kelompok LGBT dalam memperjuangkan haknya untuk menikah dan membangun keluarga. Hal ini menandakan bahwa realitas yang sama bisa dimaknai secara berbeda oleh dua kubu yang berseberangan.

Dalam analisis visual tayangan, pembahasan ini dilakukan sebagai bahan pendukung analisis teks dengan menginterpretasi video tayangan Debat Episode "Nikah Sesama Jenis, Manusiawi atau Eksistensi?", 6 Juli 2015. Interpretasi dilakukan dengan cara memperhatikan tayangan dengan seksama setiap detiknya, dari segi visual yang terlihat (teknik pengambilan gambar dan gestur tubuh), serta audio yang sedang terdengar. Hal ini tidak memungkiri jika visual yang ditampilkan juga menjadi salah satu penguat mediasi ideologi yang dilakukan oleh redaksi $T V$ One.

Teknik yang mendominasi dalam proses penggambilan gambar pada tayangan ini adalah Medium Shot (MS) di mana sesuai dengan buku Kamera dan Video Editing oleh Christianto Widjaja menyatakan bahwa shot ini menyajikan objek manusia ditampakkan dari atas pinggang sampai di atas kepala, sehingga objek menjadi lebih besar dan dominan. MS digunakan untuk mengetahui apa yang sedang dipegang dan dilakukan oleh objek. Dengan memperlihatkan subjek orang dari tangan hingga ke atas kepala, maka penonton akan dapat melihat dengan jelas ekspresi dan emosi dari wawancara yang sedang berlangsung (2008:49).

Dengan teknik ini, sang juru kamera berusaha memperlihatkan gestur, mimik, dan ekspresi dari sejumlah narasumber saat sedang beragumen, seperti terdiam, tertawa, menggerakkan jemari, atau menunjuk-nunjuk ke arah lawan debatnya saat dari masingmasing kubu ingin membantah pernyataan yang keluar dari mulut mereka.

Secara garis besar, hasil analisis visual tayangan menunjukkan bahwa teknik pengambilan gambar (framing) yang digunakan dalam tayangan ini turut menjadi penguat 
dari setiap teks yang muncul dari setiap pertanyaan maupun pernyataan dari host dan juga para narasumber dari kedua kubu. Jika teks tersebut dilengkapi dengan visual yang mendukung, maka mediasi ideologi, baik hegemoni maupun kontra hegemoni, akan sukses tersampaikan bagi publik yang menyaksikannya. Kehadiran penonton di studio yang mayoritas adalah mahasiswa juga merupakan salah satu faktor yang mempengaruhi terbentuknya teks yang muncul. Pengaruh tersebut muncul seperti reaksi tepuk tangan, celetukan, atau tertawa heboh saat host maupun dari para narasumber sedang berbicara.

Dalam pembahasan mengenai relasi dilakukan dengan cara mengetahui bagaimana hubungan antara wartawan, khalayak media, dan partisipan publik ditampilkan dan digambarkan dalam teks. Dalam tayangan ini, relasi terjalin dalam 3 dimensi, yakni kubu pro yang mewakili khalayak media, kubu kontra sebagai partisipan publik, dan host yang dalam konteks ini diposisikan sebagai wartawan. Titik perhatian dari analisis hubungan, bukan pada bagaimana partisipan publik tadi ditampilkan dalam media (representasi), tetapi bagaimana pola hubungan di antara ketiga partisipan tersebut.

Dalam tayangan ini, hubungan antara host (beserta redaksi) dengan kubu pro dari segmen 1 hingga segmen 3 masih berjalan dengan lancar. Masing-masing narasumber diberikan kesempatan dengan terbuka untuk memberikan argumen. Dede memaparkan bahwa ia sepakat wacana pernikahan sesama jenis belum bisa diwujudkan untuk saat ini, namun bisa saja dilegalkan apabila negara tergugah untuk berusaha melakukan perubahan hukum atau dengan kata lain adalah dengan melakukan amendemen terhadap undang-undang. Yuli pun sependapat dengan pernyataan Dede, namun untuk saat ini Yuli sendiri ingin lebih fokus kepada bagaimana kelompok LGBT itu sendiri agar diakui keberadaannya oleh negara, serta tidak didiskriminasi dan mendapatkan perlakuan kekerasan dari masyarakat Indonesia. Jeremy sebagai narasumber pelengkap kubu pro juga menyatakan dukungannya bahwa menikah dengan sesama jenis adalah sesuatu yang sah apabila keluarga dari individu yang bersangkutan serta perangkat hukum di Indonesia sudah merasa siap untuk menerimanya.

Akan tetapi, ketika sudah sampai pada segmen 4 dan 5, Dwi mulai menunjukkan tandatanda diskriminasi terhadap para narasumber di kubu pro. dengan sering memotong atau tidak memberikan kesempatan bagi Dede maupun Yuli untuk menyelesaikan sanggahannya dalam menanggapi argumen dari kubu kontra.

Sikap Dwi tersebut secara tersirat menunjukkan bahwa dirinya sebagai representasi dari tim redaksi TV One ingin mengagalkan kontra hegemoni ideologi yang sedang dilancarkan oleh kubu pro bahwa wacana ini sejatinya bisa dilaksanakan dalam beberapa puluh tahun ke depan apabila negara mau melakukan amendemen terhadap undang-undang.

Hubungan antara host (beserta redaksi) dengan partisipan publik, yakni para narasumber di kubu kontra tidak jauh berbeda dengan kubu pro dalam segmen 1-3, di mana Dwi hanya sekadar mengikuti alur dari perdebatan tanpa memihak satu sama lain. Namun sebaliknya pada segmen 4 dan 5, Dwi mulai cenderung memperlihatkan keberpihakannya terhadap kubu kontra dengan beberapa kali mengulang pernyataan yang keluar dari kubu kontra, khususnya Sodik Mudjahid. Tindakan mengulang pernyataan/ucapan yang keluar dari orang lain adalah bentuk bahwa seseorang secara tidak sadar telah menyetujui pernyataan tersebut. 
Puncak dari keberpihakan Dwi terhadap kubu kontra terlihat di segmen 5, di mana di saat sudah sampai pada penghujung acara, ia hanya meminta simpulan terakhir dari narasumber di kubu kontra sebagai penutup. Hal ini cukup terlihat ketika Dwi tidak memperbolehkan kubu pro untuk menyela argumen kubu kontra. Namun ketika masingmasing narasumber di kubu kontra ingin memberikan tanggapan, Dwi memberikan kesempatan kepada mereka secara terbuka. Maka dari itu, dapat disimpulkan bahwa tayangan ini telah menunjukkan keberpihakan dari redaksi TV One yang direpresentasikan melalu Dwi sebagai host terhadap kubu kontra.

Dengan kata lain, Dwi sebagai representasi dari tim redaksi TV One ingin mempertahankan dan melanggengkan hegemoni ideologi yang sedang dilancarkan oleh kubu kontra, di mana wacana pernikahan tidak dapat diakui di tanah air, karena akan banyak hal yang dilanggar jika wacana ini dilegalkan. Hegemoni ini dilakukan agar publik yang menyaksikannya dapat terpengaruh kemudian timbul konsensus yang benar dan wajar akan ideologi tersebut. Hegemoni sendiri merupakan suatu upaya keras untuk memenangkan 'perang' terhadap setiap perlawanan yang muncul (Simon, 2001).

Untuk hubungan antara kubu kontra sebagai khalayak media dan kubu pro sebagai partisipan publik, secara garis besar, masing-masing narasumber telah menerapkan pemaknaan dari kata 'debat' itu sendiri di mana kedua kubu saling memperkuat dan mempertahankan pendapatnya masing-masing. Ketika kubu kontra menolak wacana pernikahan sesama jenis di Indonesia dengan mengacu pada landasan hukum seperti UUD 1945 dan Pancasila, kubu pro juga tetap berpegang teguh dengan argumen bahwa hukum tetap bisa berubah, yaitu dengan dilakukan amendemen terhadap undang-undang.

Akan tetapi, tak bisa dipungkiri bahwa ada saatnya ketika kubu pro merasa sepakat dengan beberapa argumen kubu kontra. Situasi ini terjadi di saat Dede dan Yuli sepakat dengan Neng dan Sodik bahwa wacana pernikahan sesama jenis tidak bisa diakui, setidaknya bagi mereka untuk saat ini. Namun bagi Dede dan Yuli, wacana ini memiliki kemungkinan untuk bisa dilegalkan dalam beberapa puluh tahun ke depan ketika sudah terjadi perubahan hukum di Indonesia. Pada bagian lainnya, kubu pro sepakat dengan kubu kontra bahwa dalam konteks menghasilkan keturunan pun diperlukan kehadiran seorang laki-laki dan perempuan. Akan tetapi, dalam penerapannya dalam konteks keluarga dari pernikahan sesama jenis, bagi mereka, keturunan hanya dapat dihasilkan melalui penyewaan rahim

Pada aspek identitas, menurut Fairclough adalah bagaimana identitas wartawan ditampilkan dan dikonstruksi dalam sebuah pemberitaan. Yang menarik menurutnya adalah bagaimana wartawan menempatkan dan mengidentifikasi dirinya dengan masalah atau kelompok sosial yang terlibat. Bagaimana pembawa acara mengidentifikasi dirinya sebagai bagian dari kelompok mana? Apakah dari bagian khalayak? Ataukah menampilkan dan mnengidentifikasi diirnya secara mandiri (Eriyanto, 2012:303-304).

Berangkat dari pernyataan ini dan hasil analisis sementara, Dwi Anggia selaku host secara implisit menampilkan dirinya sebagai orang yang berpihak dalam menolak wacana pernikahan sesama jenis di Indonesia. Hal ini terlihat dari sikapnya yang cenderung memberi kesempatan lebih banyak kepada kubu kontra untuk mengutarakan pendapatnya, serta sikapnya yang beberapa kali mengulang kembali pernyataan yang keluar dari kubu kontra 
yang dianggap sebagai bentuk persetujuan secara tersirat. Puncak keberpihakan dapat dilihat dari pernyataan terakhir dari Dwi sebagai bentuk simpulan sebelum tayangan berakhir, yakni "Hak asasi adalah hak dasar manusia untuk hidup, namun ada baiknya diterapkan dengan tanpa menabrak norma hukum dan juga norma agama”.

Pada simpulannya tersebut, penggunaan kata "hak asasi" oleh host mengacu pada salah satu hak asasi dari kelompok LGBT, yakni untuk menikah dan membangun keluarga. Akan tetapi, hak ini bagi Dwi tidak baik untuk dilaksanakan karena akan menabrak norma hukum dan norma agama. Kata "menabrak" sendiri oleh Dwi secara tidak langsung telah merujuk pada bentuk sindiran terhadap kubu pro bahwa pernikahan sesama jenis adalah bentuk dari pelanggaran norma itu sendiri yang telah disebutkan oleh kubu kontra sepanjang debat berlangsung. Dengan kata lain, pernyataan ini merujuk pada simpulan bahwa tayangan ini tidak menerapkan prinsip keberimbangan.

Selanjutnya intertekstualitas di mana praktik dalam analisis intertekstualitas menurut Fairclough (dalam Eriyanto, 2012:315-316), di antara institusi dihubungkan dengan rantai intertekstualitas, serangkaian tipe dari teks yang dihubungkan antara satu dengan yang lain, sehingga bentuknya teratur dan dikonsumsi oleh khalayak.

Pada penelitian ini, peneliti berupaya melihat wacana pernikahan sesama jenis oleh $T V$ One yang nyatanya juga muncul pada Viva.co.id, media online yang sama-sama berada di naungan perusahaan yang sama, yakni PT Visi Media Asia Tbk. Dari media ini, peneliti menemukan enam berita yang mengangkat soal pernikahan sesama jenis. Dua berita pertama sejatinya telah dimuat pada tahun 2012 dan 2013. Berita pertama membahas tentang presiden Barack Obama yang mendukung pernikahan sesama jenis, sedangkan berita kedua mengenai Mahkamah Agung yang mencabut larangan pernikahan sejenis di California.

Di sisi lain, empat berita selanjutnya dimuat pada tahun 2015, di saat pernikahan sejenis telah dilegalkan di seluruh negara bagian Amerika Serikat. Berita ketiga hanya membahas tentang putusan yang dikeluarkan oleh Mahkamah Agung Amerika Serikat tersebut. Berita keempat konteksnya lebih ke arah nasional, di mana berita ini memaparkan pernyataan dari anggota DPR bahwa pernikahan sesama jenis di Amerika tidak akan berpengaruh ke Indonesia. Berita kelima masih berkaitan dengan berita keempat, namun lebih membahas penolakan akan pernikahan sejenis dari Menteri Agama, Lukman Saifuddin. Sedangkan berita keenam menceritakan bahwa pelawak Aming ikut meramaikan parade gay di New York, Amerika Serikat sebagai bentuk perayaan atas wacana pernikahan sesama jenis yang baru saja dilegalkan di negara tersebut.

Cuplikan gambar berita dari Viva.co.id ini, yakni berita pertama, kedua, dan kelima digunakan oleh redaksi Debat menjadi bahan footage yang ditayangkan pada awal tayangan Debat episode "Nikah Sesama Jenis. Manusiawi atau Eksistensi?" sebagai pengantar sebelum diskusi berlangsung.

Penggunaan berita Viva.co.id oleh redaksi TV One yang notabenenya berasal dari perusahaan yang sama mencerminkan salah satu konsep dalam Teori Hierarki Pengaruh yang diperkenalkan oleh Shoemaker dan Reese. Konsep ini selaras pada lingkaran kedua, yakni faktor rutinitas media di mana media rutin terbentuk oleh tiga unsur yang saling berkaitan, yaitu sumber berita, organisasi media, dan audiens. Ketiga unsur ini saling berhubungan dan 
berkaitan, dan pada akhirnya membentuk rutinitas media yang membentuk pemberitaan pada sebuah media (Shoemaker dan Reese, 1996). Dengan kata lain, keterkaitan antara Viva.co.id dan $T V$ One menjadi salah satu faktor pembentuk dari tayangan Debat episode "Nikah Sesama Jenis. Manusiawi atau Eksistensi?".

\section{Level Praktik Wacana}

Analisis praktik wacana memusatkan perhatian pada bagaimana produksi (di pihak media) dan konsumsi teks (di pihak khalayak). Teks berita melibatkan praktik diskursus yang rumit dan kompleks. Praktik wacana inilah yang menentukan bagaimana teks tersebut terbentuk (Eriyanto, 2012:316-317).

Setidaknya ada 3 aspek penting dalam praktik diskursif. Pertama, dari sisi individu wartawan itu sendiri. Kedua, dari sisi bagaimana hubungan antara wartawan dengan struktur organisasi media. Ketiga, praktik kerja/rutinitas kerja dari produksi berita. Ketiga elemen tersebut merupakan keseluruhan dari praktik wacana dalam suatu media yang saling kait dalam memproduksi suatu wacana berita (Eriyanto, 2012:317)..

Pembawa acara atau host dari program Debat adalah Dwi Anggia. Dwi yang sejak kecil tumbuh besar di Padang, Sumatera Barat menempuh pendidikan di jurusan Agribisnis, Sosial Ekonomi Pertanian di Universitas Andalas. Lalu, ia memutuskan untuk terjun ke media dengan menjadi penyiar di radio Arbes Padang pada tahun 2002. Setelah 2 tahun lamanya, ia kemudian memutuskan untuk bergabung dengan TVRI Sumbar pada tahun 2004. Kemudian ia pindah ke SCTV mulai tahun 2005 hingga pertengahan 2008. Dari SCTV, Dwi pindah lagi ke saluran ANTV dan bekerja di media tersebut selama 2 tahun. Dikarenakan 2 televisi sebelumnya bukan merupakan televisi berita, maka Dwi mencoba untuk bergabung ke $T V$ One pada tahun 2011 hingga saat ini dengan harapan dapat mendapatkan tantangan yang berbeda.

Dalam melihat konstelasi media di tengah situasi ekonomi dan politik, Vincent Mosco memiliki tiga konsep penting untuk mendekatinya, yakni: komodifikasi, spasialisasi, dan strukturasi. Salah satunya, yakni komodifikasi berhubungan dengan bagaimana proses transformasi barang dan jasa beserta nilai gunanya menjadi suatu komoditas yang mempunyai nilai tukar di pasar. (Mosco, 1996:212). Latar belakang dari Dwi ini secara tidak langsung mengarah pada konsep ekonomi politik media tersebut.

Dalam konteks ini, latar belakang Dwi yang telah berpengalaman di industri penyiaran berkorelasi dengan salah satu dari tiga tipe komodifikasi, yakni "komodifikasi tenaga kerja". Konsep ini mengatakan bahwa tenaga pekerja komunikasi yang juga dikomodifikasi sebagai buruh upahan telah tumbuh secara signifikan dalam pasar kerja media (dalam Ibrahim dan Akhmad, 2014). Dalam menghadapi komodifikasi ini, TV One merekrut Dwi Anggia yang sudah berpengalaman bekerja di berbagai stasiun televisi untuk bergabung bersamanya. Upaya ini tentunya kembali lagi dengan konsep komodifikasi, di mana dalam hal ini Dwi Anggia sebagai "tenaga kerja" akan ditransformasi menjadi sebuah keuntungan, yakni mempercayakannya sebagai host dalam program Debat.

Pada saat itu, Dwi memiliki tanggung jawab terhadap 2 program di TV One, yakni program berita harian Kabar Petang dan program talkshow mingguan, yaitu Debat. Di program Kabar Petang, Dwi bertugas di bagian produksi di mana ia bertugas untuk membuat 
naskah dan paket berita. Sedangkan untuk di program Debat sendiri, Dwi hanya bertugas sebagai host (pembawa acara) dan tidak cukup terlibat dalam proses produksi. Namun untuk tahap pra-produksi, Dwi masih dilibatkan untuk penentuan tema/topik dan pemilihan narasumber.

Produksi teks berhubungan erat pada bagaimana pola dan rutinitas pembentukan berita di meja redaksi. Menurut Eriyanto, proses ini melibatkan banyak orang dan banyak tahapan (20112:319). Dalam konteks ini, rutinitas tersebut dijalankan oleh tim redaksi, penulis naskah, hingga para narasumber yang terlibat di dalam tayangan. Praktik itu merupakan rutinitas media yang sedikit banyak akan berpengaruh terhadap pemberitaan

Yanne Trisnawati selaku asisten produser memaparkan bahwa konsep dari program Debat secara garis besar memang dibangun untuk membahas suatu tema yang sifatnya pro dan kontra. Selain itu, tema tersebut juga merupakan isu terkini dan sedang hangat diperbincangkan oleh publik (current issue), karena format program ini merupakan live (langsung).

Dengan mengangkat wacana pernikahan sejenis yang saat itu sedang menimbulkan polemik di tanah air, tim redaksi TV One kemudian menyiarkan berbagai macam opini yang mencerminkan kemajemukan masyarakat dengan menghadirkan narasumber dari sisi pro dan kontra. Terlebih lagi, kedua narasumber dari kubu pro merupakan bagian dari komunitas LGBT itu sendiri.

Proses pencarian isu ini sendiri dilakukan pada hari Selasa hingga Kamis. Tim redaksi akan melakukan riset mengenai isu apa yang sedang berkembang pada saat itu agar kemudian diusulkan pada rapat finalisasi di hari Jumat. Dalam konteks episode ini, saat itu tanah air sedang dihebohkan akan peristiwa legalisasi pernikahan sesama jenis di Amerika Serikat terhadap 50 negara bagiannya. Kemudian, Yanne menjelaskan bahwa tim redaksi memiliki ketertarikan dan lalu sepakat untuk mengangkat isu ini ke dalam program Debat.

Setelah topik disetujui, tim redaksi kemudian memilih dan saling memberi usulan mengenai siapa narasumber yang sekiranya dapat diundang untuk beradu argumen dari sisi pro dan kontra. Muncullah nama Dede Oetomo, Yuli Rustinawati, dan Jeremy Teti untuk kubu pro, serta nama Neng Zubaidah, Sodik Mudjahid, dan Musni Umar selaku yang mewakili kubu kontra.

Dede dan Yuli dipilih sebagai narasumber yang pro karena keduanya merupakan bagian dari komunitas LGBT itu sendiri, di mana Dede selaku pelopor gerakan kaum gay di Indonesia mewakili komunitasnya yang bernama Gaya Nusantara (Surabaya), sedangkan Yuli merupakan aktivis dari komunitas LGBT Arus Pelangi (Jakarta). Untuk Jeremy Teti sendiri diusung karena tampilannya yang dianggap kewanita-wanitaan, serta mewakili publik figur yang dinilai mendukung gerakan LGBT. Alasan Yanne ini kemudian membuktikan bahwa suatu tayangan televisi tak lepas dari fungsi komunikasi massa lainnya, yakni fungsi hiburan (Dominick dalam Effendy, 2011:31).

Dari kubu kontra sendiri, redaksi sengaja memilih narasumber yang kuat dalam bidang agama, sehingga mereka tertarik untuk mengundang Neng selaku perwakilan dari Majelis Ulama Indonesia (MUI) dan juga Sodik Mudjahid dari Komisi VIII yang salah satu ruang lingkupnya merupakan bidang agama. Komisi ini sendiri dinilai oleh tim redaksi dapat 
membahas wacana pernikahan sejenis dari segi peraturan perundang-undangan di Indonesia, khususnya mengenai Undang-undang Perkawinan dan pidana yang terkait mengenai LGBT. Sedangkan Musni selaku Sosiolog diundang sebagai pengamat yang setelah diketahui redaksi juga merupakan pribadi yang sangat kuat akan ilmu agamanya.

Di satu sisi, dengan adanya alasan-alasan tertentu dalam memilih narasumber untuk hadir dalam tayangan ini, tim redaksi $T V$ One secara tidak langsung telah melakukan "komodifikasi isi". Salah satu tipe komodifikasi ini bermakna ketika pesan atau isi komunikasi diperlakukan sebagai komoditas, ekonomi politik cenderung memusatkan kajian pada konten media dan kurang pada khalayak media dan tenaga kerja yang terlibat dalam produksi media (Mosco dalam Ibrahim dan Akhmad, 2014:20-21).

Pada intinya, alasan pemilihan dari setiap narasumber yang diundang oleh redaksi tentunya akan berpengaruh terhadap teks yang muncul, khususnya bagi mereka yang dapat menjadi "bumbu" atau dapat menghadirkan diskusi yang menarik ke dalam tayangan. Jika teks ini dapat menarik perhatian publik, maka redaksi akan mendapatkan keuntungan melalui kenaikan rating dan share.

Selain berbentuk debat, menghadirkan narasumber dari pro dan kontra, ditayangkan secara live, format dalam program ini juga menghadirkan audiens sebanyak 300 orang yang mayoritas terdiri dari kalangan mahasiswa. Mahasiswa sendiri dipandang sebagai pribadi yang notabenenya memiliki nilai kritis yang lebih dalam memandang suatu isu.

Pertimbangan dalam menjadikan mahasiswa sebagai penonton di studio ini kemudian mencerminkan salah satu konsep dalam Teori Hierarki Pengaruh yang diperkenalkan oleh Shoemaker dan Reese. Konsep ini selaras pada lingkaran kedua, yakni faktor rutinitas media di mana media rutin terbentuk oleh tiga unsur yang saling berkaitan, yaitu sumber berita, organisasi media, dan audiens. Ketiga unsur ini saling berhubungan dan berkaitan, dan pada akhirnya membentuk rutinitas media yang membentuk pemberitaan pada sebuah media (Shoemaker dan Reese, 1996). Dengan kata lain, diutamakannya mahasiswa sebagai audiens menjadi salah satu faktor pembentuk dari tayangan Debat episode "Nikah Sesama Jenis. Manusiawi atau Eksistensi?".

Akan tetapi, tidak menutup kemungkinan bagi redaksi mengundang audiens yang terkait dengan tema yang sedang diangkat. Untuk episode ini, redaksi secara khusus mengundang anggota komunitas Arus Pelangi yang berdomisili di Jakarta sebanyak 30 orang. Kehadiran dari para audiens dalam tayangan ini dinilai memiliki fungsi untuk meramaikan suasana dan membuat tayangan menarik. Walaupun pro dan kontra diskusi berjalan dengan cukup tegang, kehadiran audiens yang bertepuk tangan ataupun berteriak dipercaya mampu untuk mencairkan suasana. Di sisi lain, pemirsa di rumah juga akan lebih punya daya ketertarikan dan timbul rasa penasaran saat melihat reaksi dari audisens di studio.

Dalam pengeksekusian isu LGBT, baik mengenai kelompok LGBT itu sendiri maupun wacana pernikahan sesama jenis yang tertuang dalam tayangan ini, Yanne mengaku bahwa sebagai stasiun televisi, redaksi $T V$ One merasa tidak boleh terlalu memberi ruang kepada kelompok LGBT untuk berpendapat. Hal ini dikarenakan pada tayangan ini, Yanne menilai pernyataan-pernyataan dari Dede dan Yuli cukup "dalam" mengenai posisi dan kedudukan kaum LGBT di Indonesia pada saat itu. Maka, redaksi memilih jalan keluar dengan cukup 
menunjukkan keberpihakan kepada kubu kontra dengan harapan bahwa tayangan ini tidak akan melanggar kode etik dan undang-undang penyiaran.

Pernyataan dari Yanne ini sendiri tidak dapat dipertanggungjawabkan, karena selama diskusi berlangsung, Dede dan Yuli sebagai representasi dari komunitas LGBT tidak menunjukkan adanya sikap yang "kebanci-bancian" dalam memberikan argumen. Selain itu, pernyataan Yanne juga kontradiktif dengan aturan Pedoman Perilaku Penyiaran dan Standar Program Siaran (P3SPS) yang dikeluarkan oleh Komisi Penyiaran Indonesia perihal perlindungan penyiaran mengenai kelompok LGBT yang dimaknai sebagai kelompok marjinal atau kelompok masyarakat tertentu, yakni pada Pasal 4 (ayat i), Pasal 5 (ayat h), Pasal 6, Pasal 7, Pasal 15 (ayat 1).

Dengan kata lain, tim redaksi dinilai hanya ingin sekadar mengelak dari kenyataan bahwa KPI saja menerima dan mengakui keberadaan kelompok LGBT untuk berada di layar televisi. Terlebih lagi, pasal-pasal ini merupakan hasil advokasi antara KPI dan organisasiorganisasi LGBT yang berkampanye melawan program yang men-stigmatisasi orang LGBT dan orang yang mengekspresikan nonkonformitas dalam hal gender.

Salah satu unsur yang dibahas dalam praktik wacana selain sisi individu wartawan dan produksi teks adalah konsumsi teks. Pada bagian ini, peneliti menganalisis bagaimana teks dalam tayangan mengenai wacana pernikahan sesama jenis di Indonesia dalam program Debat episode "Nikah Sesama Jenis, Manusiawi atau Eksistensi?" di TV One dikonsumsi oleh para pemirsa.

Dalam konteks reaksi publik akan tayangan ini, tim redaksi mengetahuinya dari media sosial Twitter. Ia bersama tim redaksi yang lain memantau seperti apa tanggapan masyarakat setelah redaksi $T V$ One berani mengupas wacana pernikahan sesama jenis ke dalam program Debat. Yanne melihat bahwa perdebatan yang telah mereka sajikan di layar televisi juga tergambarkan di media sosial Twitter, di mana opini publik sendiri juga terbagi atas 2 kubu, yakni pro dan kontra dalam memandang isu ini. Dengan kata lain, hegemoni dan kontra hegemoni ideologi dari kedua kubu yang berseberangan berhasil mempengaruhi publik sesuai dengan ideologi yang mereka yakini.

Reaksi dari publik tidak melulu hanya berupa tanggapan dari media sosial. Dalam dunia penyiaran, reaksi publik yang cukup dapat dirasakan oleh para pekerja media, khususnya di industri penyiaran televisi adalah berharap tayangannya tersebut dapat berpengaruh terhadap rating dan share. Berdasarkan data dari Nielsen Indonesia, episode "Nikah Sesama Jenis, Manusiawi atau Eksistensi" edisi 6 Juli 2015 ini berhasil menaikkan rating dan share program Debat, di mana rating sebanyak 0,2\% dan share sebanyak 1,4\%.

Dengan kata lain, tim redaksi terbukti telah melakukan salah satu konsep ekonomi politik media Mosco, yakni "komodifikasi isi". Upaya-upaya yang dilakukan oleh tim redaksi, antara lain; Pertama, mengangkat isu yang sekiranya sedang menjadi polemik oleh publik dari sisi pro dan kontra. Dikarenakan Amerika Serikat baru saja melegalkan pernikahan sejenis terhadap 50 negara bagiannya dan isu ini dinilai membuat pergerakan kelompok LGBT semakin masif di tanah, maka diangkatlah wacana pernikahan sesama jenis di Indonesia oleh tim redaksi. 
Volume 01 Nomor 02 Tahun 2018

Kedua, tim redaksi memilih narasumber yang sangat vokal dalam mengutarakan argumennya, dengan kata lain narasumber tersebut dapat mengadu dan mempertahankan pendapatnya dengan narasumber yang lain. Dikarenakan tim redaksi sendiri kontra akan wacana ini, maka pencarian narasumber yang vokal diutamakan untuk kubu yang kontra, sehingga muncul nama Neng Zubaidah, Sodik Mudjahid, dan Musni Umar.

Ketiga, tim redaksi mempersiapkan hal-hal yang sekiranya dapat membuat suatu tayangan menarik untuk ditonton oleh banyak orang. Dalam episode ini, tim redaksi sengaja mengundang Jeremy Teti selaku publik figur yang mereka nilai sebagai lelaki dengan perilaku feminin serta pribadi yang mudah mengundang tawa. untuk menjadi narasumber di kubu pro. Tindakan ini dimaknai oleh tim redaksi agar situasi diskusi tidak melulu serius dan pemirsa tidak merasa jenuh saat sedang menonton tayangan ini.

\section{Level Praktik Sosiokultural}

Analisis praktik sosiokultural didasari oleh asumsi bahwa konteks sosial yang ada di luar media mempengaruhi bagaimana wacana yang muncul dalam media. Hal ini akan menggambarkan bagaimana kekuatan-kekuatan yang ada dalam masyarakat memaknai dan menyebarkan ideologi yang dominan kepada masyarakat. Fairclough membuat 3 level analisis pada praktik sosiokultural, yakni level situasional, institusional, dan sosial (dalam Eriyanto, 2012:320-322).

Aspek situasional menjadi perhatian, karena akan memperlihatkan bagaimana kondisi teks tersebut diproduksi di mana teks tersebut dihasilkan dalam suatu kondisi yang khas, unik, sehingga teks bisa jadi berbeda dengan teks yang lain (Eriyanto, 2012:322).

Pada 26 Juni 2015, Mahkamah Agung Amerika Serikat melegalkan pernikahan sesama jenis terhadap 50 negara bagiannya. Wacana ini kemudian memunculkan pro dan kontra bagi masyarakat Indonesia, khususnya publik figur dan pemerintah. Berangkat dengan situasi tersebut, redaksi $T V$ One kemudian mengangkat isu sensitif ini ke dalam suatu program berbentuk diskusi, yaitu program Debat pada 6 Juli 2015 dengan judul "Nikah Sesama Jenis, Manusiawi atau Eksistensi?". Tujuan dari program ini dikatakan untuk membahas isu-isu yang sedang menjadi perbincangan oleh publik dari sisi pro dan kontra.

Melalui tayangan ini, redaksi terlihat memiliki tujuan baik, di mana redaksi secara berani mengangkat isu yang menyangkut LGBT ini ke hadapan publik dengan landasan bahwa kaum ini eksistensinya benar-benar ada di Indonesia, sehingga masyarakat perlu sadar akan hal ini. Kemudian di satu sisi, redaksi juga ingin memberikan ruang kepada kelompok LGBT dalam menyuarakan pergerakannya yang selama ini dianggap dilakukan secara tertutup.

Meskipun tayangan ini pada akhirnya cenderung berpihak kepada kubu kontra dan hegemoni ideologi dari mereka yang memenangkan perdebatan pada saat itu, setidaknya di satu sisi kubu pro telah berusaha melancarkan kontra hegemoni ideologi mereka kepada publik dengan menyampaikan situasi dan kondisi yang saat itu terjadi terhadap kaum LGBT di Indonesia.

Pertama, terbukti sebanyak 89,3\% LGBT di Indonesia masih banyak mendapatkan tindak kekerasan dan perlakuan diskriminatif berdasarkan penelitian yang Arus Pelangi lakukan. Padahal jika mengacu pada Undang-undang Nomor 39 Tahun 1999 tentang Hak 
Asasi Manusia disebutkan bahwa tidak boleh satu orang pun warga negara Indonesia untuk didiskriminasikan. Hal ini juga selaras dengan Pasal 28I dalam UUD 1945 yang mengatakan bahwa setiap orang berhak bebas dari perlakuan yang bersifat diskriminatif atas dasar apapun dan berhak mendapatkan perlindungan terhadap perlakuan yang bersifat diskriminatif.

Selain itu, kubu pro merasa masyarakat perlu mengingat akan adanya sila ke-5 di Pancasila yang berbunyi "keadilan bagi seluruh rakyat Indonesia". Dalam sila ini mereka ingin menekankan bahwa keadilan ini adalah untuk seluruh rakyat Indonesia, terlepas dari apapun latar belakang agama, orientasi seksual, identitas gender, dan perilaku seksualnya.

Kedua, kubu pro ingin menekankan bahwa kelompok LGBT bukanlah suatu bentuk disabilitas atau kelainan jiwa. Pernyataan ini keluar di saat kubu kontra sempat memandang kaum LGBT sebagai sesuatu yang istilahnya disable (cacat). Pandangan ini kemudian berusaha dibantah kubu pro bahwa Departemen Kesehatan telah mengeluarkan "homoseksual" dari daftar gangguan jiwa dalam Pedoman Penggolongan dan Diagnosis Gangguan Jiwa (PPDGJ) yang dirilis pada tahun 1993.

Dalam konsep Teori Modernisasi (Fakih, 1996), hal ini membuktikan bahwa sebagian masyarakat Indonesia masih belum berada dalam tahap "modernisasi", karena pemahaman bahwa LGBT adalah suatu penyakit adalah pemikiran yang dinilai masih berada dalam tahap tradisionalisme. Pemahaman ini jugalah yang kemudian akan menghambat modernitas atau berpikir maju yang sedang diarahkan oleh kubu pro kepada masyarakat untuk menuju kepada suatu perubahan.

Ketiga, pemahaman yang ingin dijelaskan oleh kubu pro kepada publik bahwa konsep keluarga tidak melulu harus terdiri dari ayah, ibu, dan anak. Bagi kubu pro, masih ada keluarga yang konsep keluarganya hanya terdiri dari ayah dan anak, atau ibu dan anak. Di masa yang akan datang pun konsep keluarga juga dinilai mungkin sudah akan berubah, termasuk dengan adanya keluarga dari hasil pernikahan sejenis.

Pada level ini, peneliti melihat bagaimana pengaruh institusi organisasi dalam praktik produksi sebuah wacana. Institusi ini bisa berasal dalam diri media sendiri, bisa juga kekuatan-kekuatan eksternal di luar media yang menentukan proses produksi berita (Eriyanto, 2012:322-323).

Dalam episode ini, Dwi Anggia selaku host dari program Debat menyatakan bahwa redaksi TV One ingin menyadarkan masyarakat bahwa komunitas LGBT ini benar-benar ada di Indonesia dan gerakannya yang semakin masif seiring berjalannya waktu. Tak hanya itu, redaksi juga ingin menjelaskan bahwa perilaku yang berunsur LGBT adalah sesuatu yang tidak benar dari segi agama dan budaya Indonesia yang menjunjung budaya Timur (erat dengan etika, moral, dan adat istiadat).

Dengan perspektif ini, redaksi secara tidak langsung telah menjalankan visi dan misi dari TV One itu sendiri, di mana sesuai dengan profil yang tertera di halaman situs TV One, visi dari $T V$ One adalah untuk mencerdaskan semua lapisan masyarakat yang pada akhirnya memajukan bangsa. Dengan kata lain, TV One secara tersirat menyatakan bahwa "mencerdaskan" dan "memajukan" masyarakat Indonesia adalah dengan menekankan ideologi bahwa LGBT adalah sesuatu yang salah dan publik perlu diberikan suatu penyadaran akan hal ini. 
Secara tersirat, visi dan misi dari TV One ini sendiri satu pemahaman dengan proses modernisasi menurut Huntington (1976), di mana proses ini sendiri bersifat "evolusioner" (perubahan cepat dari tradisi ke modern), "kompleks' (melalui banyak cara), "sistematik", "global" (akan mempengaruhi semua manusia), "bertahap" (melalui langkah-langkah), "hegemonisasi", dan "progresif" (Fakih, 1996:32). Dalam konteks ini, TV One telah mencerminkan konsep modernisasi dengan menggunakan kata "mencerdaskan", "memajukan", dan "positif" yang dinilai sebagai jalan optimis menuju perubahan dalam konsep Teori Modernisasi.

Dari segi kebijakan redaksi, Dwi menjelaskan bahwa redaksi $T V$ One sejatinya memiliki kebijakan yang memang tidak menyetujui adanya pernikahan sejenis. Dalam perwujudannya pun terbukti bahwa tim redaksi sengaja mengundang narasumber-narasumber yang memiliki latar belakang agama yang kuat untuk berada di kubu yang kontra agar dapat mempertentangkan kelompok LGBT dengan konteks agama, khususnya agama Islam sebagai agama dominan di Indonesia.

Kebijakan redaksi ini telah mencerminkan konsep dari lingkaran ketiga Teori Hierarki Pengaruh dari Shoemaker dan Reese, yakni level organisasi. Dalam konteks ini, redaksi $T V$ One sebagai organisasi media memiliki peran penting dalam mempengaruhi pemberitaan melalui keyakinan yang mereka miliki dalam memandang suatu isu yang sedang berkembang di masyarakat yang di mana mereka memang akhirnya tidak menyetujui adanya wacana pernikahan sesama jenis di Indonesia. Andromeda Mercury, salah satu news anchor yang juga bekerja di $T V$ One, menambahkan bahwa hal tersebut memang dilakukan demi kepentingan media TV One dan pemirsa itu sendiri.

Faktor sosial sangat berpengaruh terhadap wacana yang muncul dalam pemberitaan. Menurut Fairclough (dalam Eriyanto, 2012:325), wacana yang muncul dalam media ditentukan oleh perubahan masyarakat. Aspek sosial di sini akan lebih melihat pada aspek makro, seperti sistem politik, sistem ekonomi, atau sistem budaya secara keseluruhan.

Sejak 1983, Lambda Indonesia - organisasi LGBT yang didirikan oleh Dede Oetomo bersama rekan-rekannya di mana organisasi ini telah bergerak sejak tahun 1982 - telah mengaku dalam buletin Gaya Hidup Ceria bahwa pernikahan sesama jenis memang tidak bisa disahkan di negara Indonesia yang mengacu pada Pasal 1 Undang-undang Perkawinan Nomor 1 Tahun 1974.

Pada kenyataannya, menurut Dede dalam bukunya yang berjudul Memberi Suara pada yang Bisu, perkawinan homoseks pernah terjadi Indonesia. Satu pesta perkawinan lesbian pernah diekspos di media massa pada 1981, yaitu antara Jossie dan Boni di Jakarta. Mereka dinilai sangat berani oleh Dede, tetapi keberanian ini tidak disusul oleh adanya pasanganpasangan lainnya. Perhelatan semacam ini dianggap belum bisa dilakukan seperti perkawinan heteroseks yang menganggap penting untuk resminya perkawinan di muka keluarga dan masyarakat (2003:130-131).

Media massa di Indonesia pun masih dirasa masih belum siap dalam memberitakan topik mengenai LGBT secara netral. Dede menyesali bahwa pers Indonesia yang semestinya memimpin opini publik sering memandang perilaku homoseks sebagai sesuatu yang lucu dan bahan sensasi (oleh beberapa media tertentu), tetapi bukan sesuatu yang perlu secara serius 
dibahas. Misalnya, majalah Jakarta-jakarta edisi 14-20 Oktober 1989 dikatakan oleh Dede pernah menurunkan artikel berjudul "Idiih! Pria Kawini Pria" yang dianggap menunjukkan sikap penulis atau redaktur yang masih jijik, muak, atau geli melihat tingkah para homo di Denmark (Oetomo, 2003:132-133).

Dede mengupas kembali mengenai wacana pernikahan sesama jenis di Indonesia ke dalam buletin Gaya Nusantara edisi April 2006. Menurut Dede yang berprofesi sebagai dosen dan juga Sosiolog menilai bahwa pernikahan di Indonesia masih identik dengan seks dan keturunan, bukan mengutamakan kompromi antara dua manusia. Tak heran apabila masyarakat di Indonesia memiliki batasan umuran dalam menghasilkan keturunan dan menimbulkan suatu keterpaksaan bagi beberapa orang.

Pandangan yang memuat unsur paksaan inilah yang kemudian perlahan menerpa kaum LGBT. Tak sedikit gay dan lesbian yang pada akhirnya memutuskan untuk menikah dengan lawan jenis karena desakan keluarga demi menjaga status diri masyarakat atau kehormatan keluarga. Tindakan ini dinilai Dede berimplikasi bahwa seseorang tidak jujur akan identitas dan orientasi seksualnya yang pada akhirnya berpotensi pada hubungan pernikahan yang tidak lama atau istilahnya perceraian. Bahkan dalam beberapa kasus, ada beberapa kaum LGBT yang lebih memilih menolak pernikahan dan menjalani kehidupan dalam kesendirian. Situasi ini dinilainya merupakan semacam perlawanan dan pemberontakan seorang manusia terhadap suatu ketidakadilan yang ia rasakan.

Namun kembali lagi, masyarakat Indonesia mengalami perkembangan yang cukup signifikan saat legalisasi pernikahan sesama jenis di Amerikat Serikat menjadi sorotan utama dunia pada tahun 2015. Legalisasi yang ramai diberitakan oleh sejumlah media massa di tanah air ini cukup mengundang berbagai reaksi, khususnya oleh publik figur yang mulai terbuka akan isu mengenai kelompok LGBT dan juga mendukung wacana pernikahan sejenis ini.

\section{Simpulan}

Berdasarkan pembahasan yang telah dipaparkan sebelumnya, maka dalam penelitian yang berjudul "Wacana Pernikahan Sesama Jenis di TV One" ini, peneliti mengambil simpulan sebagai berikut.

Wacana penikahan sesama jenis dalam level teks menunjukkan bahwa berdasarkan Teori Hegemoni dari Gramsci, ideologi dari kubu kontra dalam menentang keras adanya wacana pernikahan sesama jenis di Indonesia sangat mendominasi tayangan ini. Dalam melihat reaksi publik di media sosial Twitter, ideologi ini pun berhasil mempengaruhi opini publik.

Lalu, sesuai dengan Editorial Guidelines: The BBC's Values and Standards, tayangan ini berhasil menerapkan prinsip keberimbangan (proporsional) dari segi menyajikan keragaman opini masyarakat, yakni dengan menghadirkan sejumlah narasumber dari kubu pro dan kubu kontra, namun tidak proporsional dalam konteks memberikan waktu berpendapat yang sama (seimbang) bagi kubu pro sebagai bagian dari kelompok LGBT.

Wacana penikahan sesama jenis dalam level praktik wacana menyimpulkan bahwa; Pertama, terjalin hubungan yang tidak dapat terlepaskan antara tim redaksi (yang terdiri dari 
Manajer, Eksekutif Produser, Produser, Asisten Produser, Reporter, serta Host), organisasi media, dan ideologi media yang bermain sesuai dengan Teori Hierarki Pengaruh dari Shoemaker dan Reese.

Kedua, tim redaksi $T V$ One menerapkan konsep ekonomi politik media, yakni Teori Komodifikasi dari Mosco terhadap tayangan Debat agar dapat meraih perhatian publik yang nantinya berimplikasi pada kenaikan rating dan share.

Ketiga, tim redaksi TV One tidak konsisten dalam menayangkan topik mengenai kaum LGBT di mana dari segi pemilihan dan pengangkatan isu, redaksi telah menerapkan konsep "giving voice to the voiceless", namun pada akhirnya tidak dibarengi dengan memberikan porsi berbicara yang seimbang antara kubu pro dengan kubu kontra saat tayangan berlangsung.

Wacana penikahan sesama jenis dalam level praktik sosiokultural memperlihatkan bahwa menurut Teori Kekuasaan dan Diskursus dalam Perubahan Sosial (Fakih, 1996), masyarakat di Indonesia masih belum siap menerima wacana pernikahan sesama jenis untuk dilegalkan di Indonesia. Namun seiring berjalannya waktu, jika mengacu pada Teori Modernisasi, sebagian masyarakat Indonesia juga telah berada dalam tahap menuju perubahan atau istilahnya "modernisasi" di mana mereka mulai memilih untuk terbuka dan menerima kehadiran dan eksistensi kaum LGBT.

\section{DAFTAR PUSTAKA}

\section{BUKU}

Effendy, Onong Uchjana. (2011). Ilmu Komunikasi: Teori dan Praktek. Bandung: Remaja Rosdakarya Offset.

Eriyanto. (2012). Analisis Wacana, Pengantar Analisis Teks Media. Yogyakarta: LKIS.

Fakih, Mansour. (1996). Analisis Gender dan Transformasi Sosial. Yogyakarta: Pustaka Pelajar.

Ibrahim, Idi Subandy \& Bachruddin Ali Akhmad. (2014). Komunikasi dan Komodifikasi: Mengkaji Media dan Budaya dalam Dinamika Globalisasi. Jakarta: Yayasan Pustaka Obor Indonesia.

Mosco, Vincent. (2009). The Political Economy Of Communication: Second Edition. London: Sage Publication.

Oetomo, Dede. (2003). Memberi Suara Pada yang Bisu. Yogyakarta: Galang Press.

Olong, Hatib Abdul Kadir. (2007). Tangan Kuasa Dalam Kelamin. Yogyakarta: INSIST Press.

Shoemaker, Pamela J., \& Stephen D. Reese. (1996). Meditating The Message: Theories of influences on Mass Media Content. London: Pearson Longman

Simon, Roger. (2001). Gagasan-gagasan Politik Gramsci: Cetakan III. Yogyakarta: Insist dan Pustaka Pelajar.

\section{UNDANG-UNDANG}


ISSN 2549-0559 (cetak) ISSN 2549-1946 (online)

Volume 01 Nomor 02 Tahun 2018

Pedoman Penggolongan dan Diagnosis Gangguan Jiwa (PPDGJ) Jilid III oleh Kementerian Kesehatan

Pedoman Perilaku Penyiaran dan Standar Program Siaran (P3SPS) oleh Komisi Penyiaran Indonesia.

Undang-undang Dasar 1945. Undang-undang Nomor 1 Tahun 1974 tentang Perkawinan.

https://id.wikipedia.org/wiki/Debat_(acara_televisi) (diakses 15 Agustus 2016 pukul 16.34)

http://www.tvonenews.tv/profil (diakses 2 September 2016 pukul 02.19) 